\title{
Etoposide induces cell death via mitochondrial-dependent actions of p53
}

\author{
Sarwat Jamil, Irene Lam, Maryam Majd, Shu-Huei Tsai and Vincent Duronio*
}

\begin{abstract}
Background: Etoposide has been used clinically in cancer treatment, as well as in numerous research studies, for many years. However, there is incomplete information about its exact mechanism of action in induction of cell death.

Methods: Etoposide was compared at various concentrations to characterize the mechanisms by which it induces cell death. We investigated its effects on mouse embryonic fibroblasts (MEFs) and focused on both transcriptional and non-transcriptional responses of p53.

Results: Here we demonstrate that treatment of MEFs with higher concentrations of etoposide induce apoptosis and activate the transcription-dependent functions of p53. Interestingly, lower concentrations of etoposide also induced apoptosis, but without any evidence of p53-dependent transcription up-regulation. Treatment of MEFs with an inhibitor of p53, Pifithrin- $\alpha$, blocked p53-dependent transcription but failed to rescue the cells from etoposideinduced apoptosis. Treatment with PES, which inhibits the mitochondrial arm of the p53 pathway inhibited etoposide-induced cell death at all concentrations tested.

Conclusions: We have demonstrated that transcriptional functions of p53 are dispensable for etoposide-induced cell death. The more recently characterized effects of $\mathrm{p} 53$ at the mitochondria, likely involving its interactions with $\mathrm{BCL}-2$ family members, are thus more important for etoposide's actions.
\end{abstract}

Keywords: Transcription, Mitochondria, DNA damage, Fibroblast, P53 acetylation

\section{Background}

p53 is recognized as the 'guardian of the genome', as its deficiency can lead to high frequency of cancer development in both mice and men due to loss of chromosome integrity [1]. The basal levels of p53 are held in check by binding to an E3 ligase Mdm2 (Hdm2 in humans) which promotes degradation of the protein [1]. In response to acute stress the interaction between $\mathrm{Mdm} 2$ and p53 decreases and levels of p53 are stabilized. Accumulation of p53 occurs predominantly in the nucleus where p53 binds to specific DNA sequences and alters the transcription of responsive genes [2]. Many p53 responsive genes are involved in the regulation of cell cycle, induction of apoptosis, or encode DNA repair enzymes. The altered

\footnotetext{
*Correspondence: vduronio@mail.ubc.ca

Department of Medicine, Jack Bell Research Centre, Vancouver Coastal Health Research Institute, University of British Columbia, 2660 Oak St.,
} Vancouver, BC V6H 3Z6, Canada activity of p53 responsive genes determines the outcome of the cell's response to stress.

The death-inducing functions of p53 are tumour suppressive, due to its ability to induce apoptosis to eliminate damaged cells. Apoptosis is initiated by the permeabilization of the outer mitochondrial membrane, which is regulated by the members of BCL-2 family. The best characterized role of p53 in this context is as a nuclear transcription factor where it up-regulates the transcription of several pro-apoptotic members of the BCL-2 family, including BAX, PUMA, NOXA and BID, and inhibits the transcription of some anti-apoptotic members such as BCL-2 and BCL- $\mathrm{X}_{\mathrm{L}}$ [3-6]. However, p53 can also induce apoptosis independently of its transcriptional function. Several apoptotic stimuli lead to the accumulation of p53 in the cytoplasm and the mitochondria are increasingly recognised as novel sites for this p53 activity. Although the complete physiological relevance of transcription-independent functions of p53 is not clear, they 
have been shown to deliver a decisive signal for apoptosis to commence $[7,8]$. p53 has also been shown to function by direct interactions with, or activation of, BCL-2 family proteins at the mitochondria $[9,10]$.

Conventional cancer therapies, including genotoxic drugs and ionizing radiation, induce DNA damage and consequently activate and stabilize p53 (reviewed in [11]). The therapeutic value of p53 activation by such drugs is severely mitigated by p53's role in causing the harmful side effects observed as a result of radiation and chemotherapy. Strategies that allow a short term blockage of p53 action in normal cells, while treating the p53 deficient tumors, therefore appear to be reasonably appealing in reducing the adverse effects of cancer therapies [1]. Two classes of small molecule inhibitors of p53 named pifithrin (PFT) have been identified, which target either the transcriptional or the mitochondrial activity of p53 $[12,13]$. While PFT- $\alpha$ prevents p53 mediated transcriptional activation and subsequent apoptosis [12], PFT- $\mu$, also known as 2-phenylethynesulfonamide or PES, and shown to have effects on HSP70 [14], was demonstrated to selectively inhibit the mitochondrial arm of p53 pathway by reducing the binding affinity of p53 to BCL-2 or BCL- $\mathrm{X}_{\mathrm{L}}$ [13]. Both drugs can offer some protection against a lethal dose of ionizing radiation.

Etoposide is a widely used drug for chemotherapy that induces DNA damage by inhibition of Topoisomerase II [15]. Ensuing DNA damage response involves cell cycle arrest and DNA repair, but eventually cell death if repair is unsuccessful. Etoposide-treated cells accumulate at $\mathrm{G} 2 / \mathrm{M}$, which can occur in both p53-dependent and -independent pathways [16]. In the p53-independent pathway the cell cycle block induced by DNA damage is controlled by ATM/ATR protein kinases. The p53-dependent pathway on the other hand achieves the arrest at $\mathrm{G} 2$ by p53 mediated repression of cyclin B1/ CDK1 promoters.

Despite the long history of studies investigating p53 and cell death by chemotherapy drugs such as etoposide, there remain a number of questions regarding the mechanism by which these processes are regulated. Previously, we found that etoposide can have differential effects on DNA damage response pathways when used at higher or lower concentrations [17]. The aim of this study was to probe the cellular and molecular events regulated by different concentrations of etoposide. We show that $1.5 \mu \mathrm{M}$ of etoposide, a clinically relevant concentration shown to be achieved in the plasma of responders [18-20], clearly induces apoptosis through the transcription-independent p53 mitochondrial pathway. Even at higher concentrations of etoposide, where transcriptional activation via p53 occurs, our evidence suggests that the mitochondrial actions of p53 are more important for induction of cell death. These results may have implications in any attempts to modulate p53 function in the context of chemotherapy treatments.

\section{Results and discussion}

Etoposide increased the numbers of cells with sub-G1 DNA content in a concentration-dependent manner

In our previous studies we have investigated the role of MCL-1 in DNA damage response by using a low concentration of etoposide $[17,21]$. To further our understanding of the differences in the cellular responses to treatment with low compared to high concentrations of etoposide, mouse embryo fibroblasts (MEFs) were treated with etoposide at different concentrations and analyzed for their apoptotic response after $18 \mathrm{~h}$. Treatment of MEFs with etoposide induced cell death, which was verified by the appearance of sub-diploid G1 peaks in flow cytometry analysis of permeabilized cells stained with propidium iodide. As shown in Fig. 1a, approximately $22 \%$ cells underwent apoptosis following treatment with $1.5 \mu \mathrm{M}$ etoposide for $18 \mathrm{~h}$, compared to $60 \%$ with $15 \mu \mathrm{M}$ and $65 \%$ with $150 \mu \mathrm{M}$ etoposide. A representative experiment showing the raw data from flow cytometry is shown in Additional file 1: Figure S1.

We next investigated the activation of caspase- 3 in response to different concentrations of etoposide. Western blot analysis with caspase- 3 antibody showed that $150 \mu \mathrm{M}$ of etoposide induces robust cleavage of caspase-3 within $6 \mathrm{~h}$ while 1.5 or $15 \mu \mathrm{M}$ activate caspase-3 only after $18 \mathrm{~h}$ (Fig. 1b). These results confirm that a low concentration of etoposide $(1.5 \mu \mathrm{M})$ is indeed able to induce apoptosis in MEFs following treatment for less than $24 \mathrm{~h}$. Thus, these conditions were subsequently used to compare effects of etoposide in inducing measurable cell death, allowing us to more carefully query any differences in the molecular responses to the various concentrations of drug.

\section{Low or high concentrations of etoposide have different effects on transcriptional regulation by $\mathrm{p} 53$}

Tumor suppressor protein p53 plays an important role in DNA damage-induced apoptosis, at least partly by acting as a transcription factor to direct the expression of apoptotic mediators. We investigated the effect of etoposide on two representative transcriptional targets of $\mathrm{p} 53$, the BH3-only pro-apoptotic protein PUMA and cell cycle inhibitor $\mathrm{p} 21^{\mathrm{CIP} 1 / \mathrm{WAF} 1}$. Our results showed that treatment of cells with $15 \mu \mathrm{M}$ of etoposide induced up-regulation of PUMA protein expression (known to be directly correlated with its p53-dependent transcription) within $1 \mathrm{~h}$, which increased further at 3 and $6 \mathrm{~h}$, before declining after $18 \mathrm{~h}$ (Fig. 2a, upper panel). A similar increase was observed in $\mathrm{p} 21^{\mathrm{CIP} 1 / \mathrm{WAF} 1} \mathrm{mRNA}$ levels, which showed 


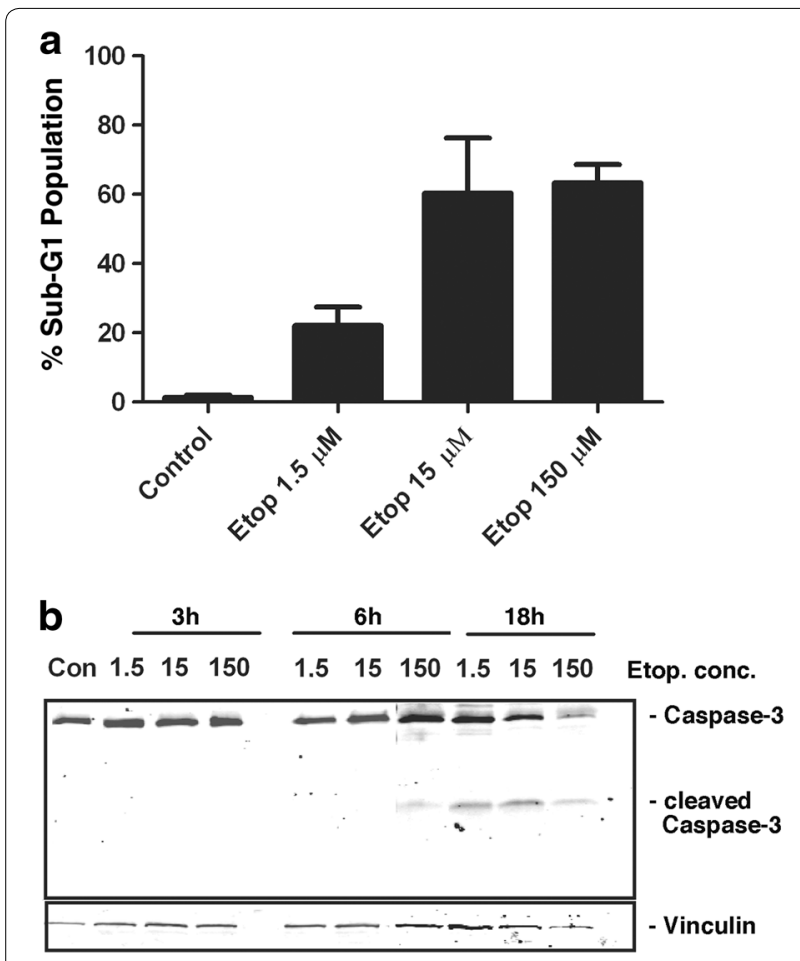

Fig. 1 Concentration-dependent etoposide-induced apoptosis. a Flow cytometry analysis of MEFs was performed to determine the percentage of cells with DNA content below the threshold for cells in G1, following $18 \mathrm{~h}$ treatment with $1.5,15$ or $150 \mu \mathrm{M}$ etoposide. Data shown are mean + SD from seven independent experiments with three replicates each. b MEFs were treated with $1.5,15$ or $150 \mu \mathrm{M}$ etoposide for 3, 6 or $18 \mathrm{~h}$. Con indicates extract from untreated cells. Total cell proteins were probed with anti-Caspase-3 antibody. Vinculin was used as the loading control. Figures are representative of three independent experiments showing similar results.

an increase at $30 \mathrm{~min}$ and remained elevated even after $18 \mathrm{~h}$ incubation (Fig. 2b, upper panel). When cells were treated similarly with $1.5 \mu \mathrm{M}$ etoposide, which can still induce substantial cell killing, no increase in the expression of either PUMA protein or $\mathrm{p} 21^{\mathrm{CIP} 1 / \mathrm{WAF} 1} \mathrm{mRNA}$ levels was observed over the same time periods (Fig. 2a, b, lower panels). These results suggested that the cell death observed in response to treatment with $1.5 \mu \mathrm{M}$ etoposide was independent of these two transcriptional events mediated by $\mathrm{p} 53$.

\section{PFT- $\alpha$ failed to rescue the cells from etoposide-induced apoptosis}

To determine whether higher concentrations of etoposide may be inducing apoptosis through the transcription-dependent actions of p53, we used the small molecule inhibitor PFT- $\alpha$. PFT- $\alpha$ has been shown to interfere with the expression of p53-inducible genes $[12,22,23]$. Although originally identified as a selective inhibitor of p53-induced transcription, it is now known

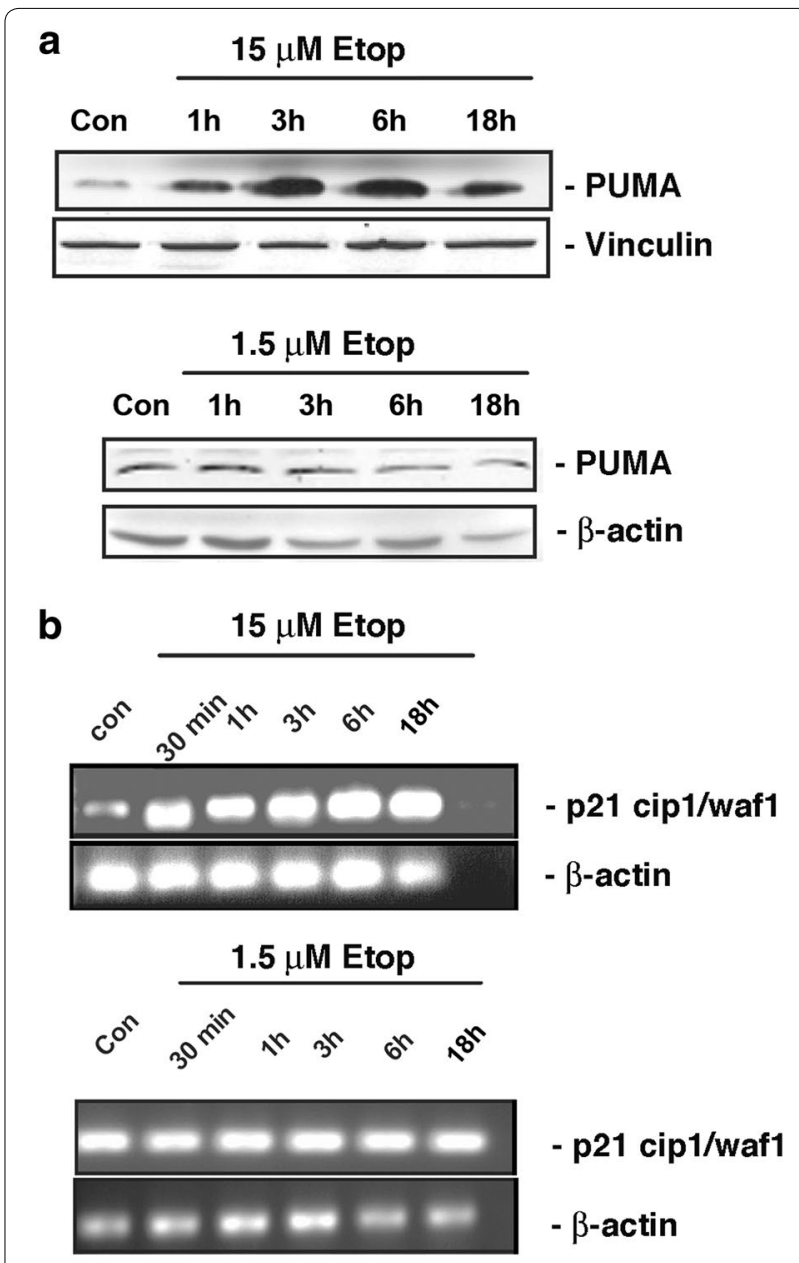

Fig. 2 Etoposide effect on p53-mediated transcriptional events. a MEFs were treated with $15 \mu \mathrm{M}$ of etoposide (upper panel) or $1.5 \mu \mathrm{M}$ of etoposide (lower panel) for 1, 3, 6 or $18 \mathrm{~h}$. Total cell proteins were probed with anti-PUMA antibody. Vinculin or actin was used as the loading control. b MEFS were treated with $15 \mu \mathrm{M}$ of etoposide (upper panel) or $1.5 \mu \mathrm{M}$ of etoposide (lower panel) for $30 \mathrm{~min}, 1,3,6$ or $18 \mathrm{~h}$. Total RNA was isolated and reverse transcribed into cDNA. The expression of $\mathrm{p} 21^{\mathrm{CIP} 1 / \text { WAF1 }}$ was determined by RT-PCR using specific primers. $\beta$-actin was used a loading control. Figures are representative of three independent experiments.

to have other p53 independent functions [24]. Pre-treatment of cells with $30 \mu \mathrm{M}$ PFT- $\alpha$, followed by $18 \mathrm{~h}$ treatment with either 1.5 or 15 or $150 \mu \mathrm{M}$ of etoposide failed to rescue the cells from DNA damage-induced apoptosis (Fig. 3a). In parallel experiments, cells were pre-treated with PFT- $\alpha$ and subsequently exposed to UVC radiation to induce DNA damage mediated apoptosis. PFT- $\alpha$ similarly failed to exert any effect on UV treatment-induced apoptosis.

The inability of PFT- $\alpha$ to rescue cells treated with any concentration of etoposide or exposure to UV radiation was intriguing. We therefore confirmed the efficacy of 

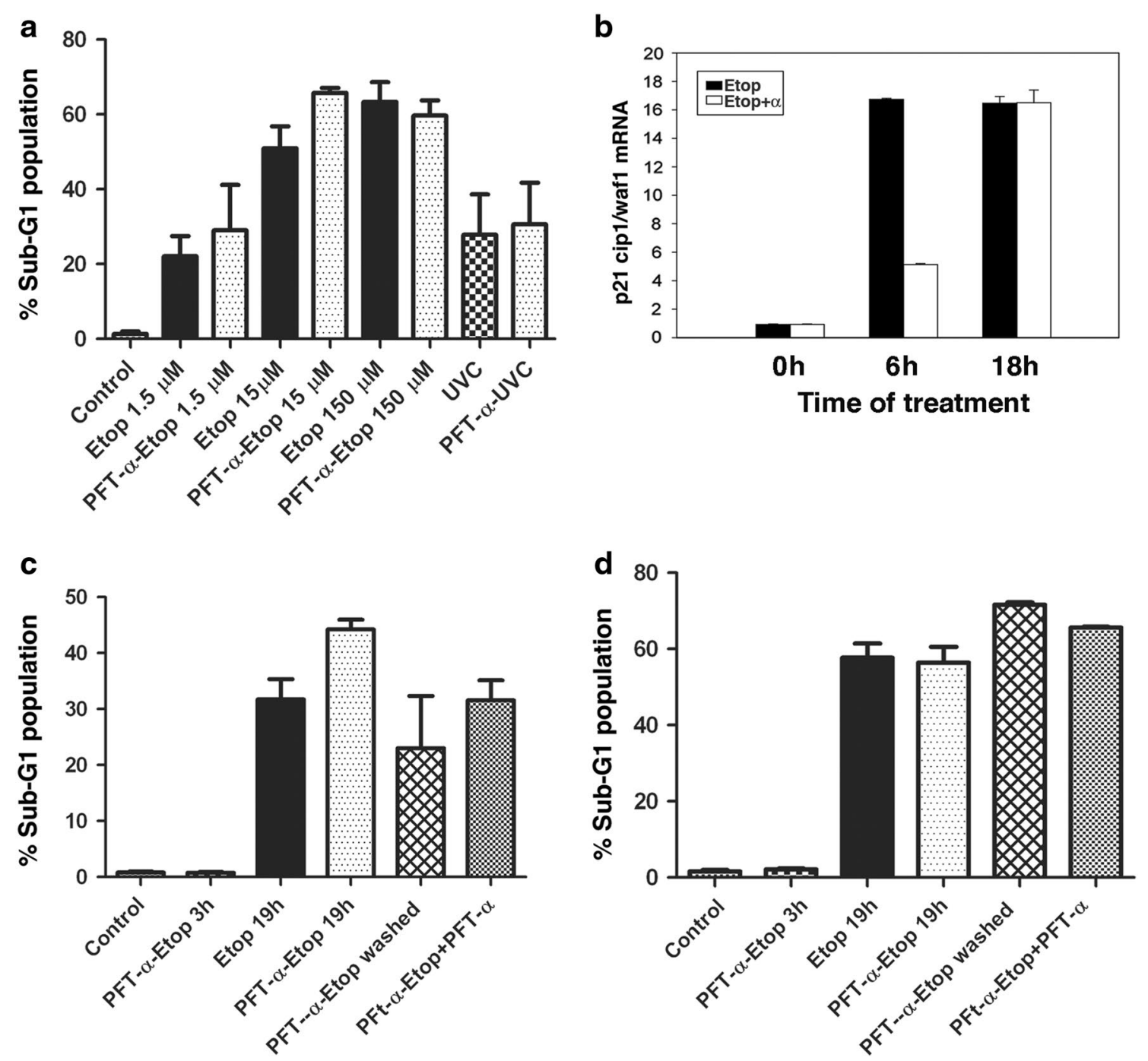

$1.5 \mu \mathrm{M}$ Etop

$15 \mu \mathrm{m}$ Etop

Fig. 3 Effect of PFT- $\alpha$ on etoposide-induced apoptosis. a MEFs, pre-treated with $30 \mu \mathrm{M}$ PFT- $\alpha$ followed by $18 \mathrm{~h}$ treatment with 1.5, 15 or $150 \mu \mathrm{M}$ etoposide, were analyzed by flow cytometry to determine percentage of cells having sub-G1 DNA content. Cells were treated in parallel with UVC and analyzed after $18 \mathrm{~h}$. Control indicates normally proliferating cells. Columns represent percentage of cells having sub-G1 DNA content, as analyzed by flow cytometry. Data are mean + SD of three independent experiments with three replicates each. $\mathbf{b}$ mRNA was extracted from untreated $(0 \mathrm{~h}), 6$ and $18 \mathrm{~h}$ treatment with $15 \mathrm{\mu M}$ of etoposide (black bars) or pre-treatment with PFT- $\alpha$ followed by etoposide (open bars). The relative expres-

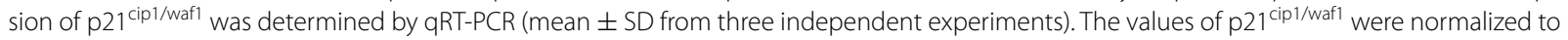
$\beta$-actin. c, d Parallel studies used 1.5 or $15 \mu \mathrm{M}$ etoposide. Sub-G1 population of MEFs was measured as in A for cells that were untreated (Control), pre-treated with $30 \mu \mathrm{M}$ PFT- $\alpha$ followed by etoposide for $3 \mathrm{~h}$ (PFT- $\alpha$-Etop $3 \mathrm{~h}$ ), etoposide alone for $19 \mathrm{~h}$ (Etop $19 \mathrm{~h}$ ), pre-treated with PFT- $\alpha$ followed by etoposide for $19 \mathrm{~h}$ (PFT- $\alpha$-Etop $19 \mathrm{~h}$ ), washed after $3 \mathrm{~h}$ of co-treatment, followed by further incubation for $18 \mathrm{~h}$ (PFT- $\alpha$-Etop washed) and washed after $3 \mathrm{~h}$, and PFT- $\alpha$ was added back for $18 \mathrm{~h}$ (PFT- $\alpha$-Etop + PFT- $\alpha$ ). Columns represent percentage of cells having sub-G1 DNA content; representative of three experiments with similar results.

PFT- $\alpha$ in inhibiting the transcriptional up-regulation of $\mathrm{p} 21^{\mathrm{CIP} 1 / \mathrm{WAF} 1}$ gene expression. MEFs were pre-treated with PFT- $\alpha$ followed by addition of $15 \mu \mathrm{M}$ etoposide for various time periods. PFT- $\alpha$ effectively inhibited the up-regulation in p $^{\text {CIP1/WAF1 }}$ for up to $6 \mathrm{~h}$ (Fig. 3b), suggesting that the drug was indeed effective in suppressing p53-regulated transcription. However, it failed to do so in cells that were treated for $18 \mathrm{~h}$, a result that may be explained based on studies showing that the half-life of PFT- $\alpha$ is approximately $5 \mathrm{~h}$ in physiological conditions 
[25]. We can conclude that blocking p53-dependent transcriptional events does not affect etoposide-induced cell death.

In another experimental approach, cells were incubated with PFT- $\alpha$ and subsequently treated with etoposide for $18 \mathrm{~h}$, or treated with PFT- $\alpha$ and etoposide for $3 \mathrm{~h}$ only, and the drug washed out prior to incubation in the presence or absence of PFT- $\alpha$ for $18 \mathrm{~h}$. Cell death was assessed by measurement of sub-G1 DNA content. While no death is detected after $3 \mathrm{~h}$ of etoposide treatment (not shown), $3 \mathrm{~h}$ treatment with either 1.5 or $15 \mu \mathrm{M}$ etoposide, followed by washing and further incubation, was sufficient to induce cell death, almost as well as continual exposure to etoposide. However, this was not affected by the presence of PFT- $\alpha$, despite its ability to block p53-mediated transcription (Fig. 3b-d). Together, these experiments support the conclusion that etoposideinduced cell death is not due to an effect on p53-dependent transcription.

\section{PES inhibits etoposide-induced apoptosis and cell cycle checkpoint response}

Since we had shown that etoposide-induced cell death is independent of p53's transcriptional regulation, we tested the effect of pre-treatment with $10 \mu \mathrm{M}$ PES. PES is a small molecule that prevents the association of p53 to the mitochondria $[13,26]$. Western blot analysis of mitochondrial extracts following etoposide treatment showed a dramatic increase in mitochondrial p53 abundance, which was blocked in PES-treated cells (data not shown). To directly assess the effect of PES on p53's interaction with a known binding partner at the mitochondria, p53 was immunoprecipitated and the immunoprecipitate was probed for BCL-xL levels. As shown in Fig. 4a, PES disrupted the $\mathrm{p} 53 / \mathrm{BCL}-\mathrm{xL}$ interaction. It should be noted that PES had little to no effect on total cellular p53 levels (see other data below). Furthermore, pre-treatment of MEFs with PES dramatically inhibited etoposide-induced generation of sub-G1 DNA content, particularly at earlier times (Fig. 4b). Moreover, PES was able to effectively block death of cells that were treated with a 10-100 fold higher concentration of etoposide over a period of $18 \mathrm{~h}$, as well as cell death induced by UVC treatment (Fig. 4c). Together, this provides further evidence that the primary means by which etoposide induces cell death is via the transcription-independent functions of p53.

The transcription independent death pathway of p53 has been suggested to occur via several possible pathways: p53 may act as a 'super' BH3-only protein and may interact with the multi domain anti-apoptotic BCL-2 family members to liberate pro-apoptotic members from inhibitory complexes [27-29] or p53 can interact directly with pro-apoptotic BAK to release cytochrome C [29].
Yet another model proposed that stress-induced cytosolic p53 is sequestered by soluble anti-apoptotic BCL- $\mathrm{X}_{\mathrm{L}}$ and transcriptional activation of PUMA displaces $\mathrm{p} 53$, which then activates monomeric cytosolic BAX to induce apoptosis [10]. Our results showing that activation of PUMA was not required are not consistent with the latter possibility, and likely support a role for $\mathrm{p} 53$ as a BH3only protein at the mitochondria.

We next investigated the cell cycle status of the MEFs in the various treatment conditions. Our results showed that in response to treatment with etoposide, MEFs undergo a DNA damage-induced arrest at the G2/M phase of the cell cycle and apoptotic cells with sub-G1 levels of DNA can be detected, as expected (Fig. 5a). Interestingly, while PFT- $\alpha$ had no effect, treatment of cells with PES overrides the etoposide-induced DNA damage checkpoint at G2/M (Fig. 5a, b). Similar results were obtained when HeLa cells were pre-treated with PES and followed by treatment with etoposide (data not shown). Etoposide is known to activate checkpoint response, which delays the progression through the cell cycle. Since the progression of cell cycle from G2 to mitosis is driven by cyclin dependent kinase CDK1 [30], it is a prime target of DNA damage response proteins for instigation of G2/M arrest. The CDK inhibitor $\mathrm{p} 21^{\mathrm{CIP1} / \mathrm{WAF} 1}$ has been shown to be up-regulated at both G1/S and G2/M checkpoints and studies of Ding et al. have reported an increase in its expression in response to etoposide treatment in a p53-dependent manner [31]. We therefore determined whether the ability of PES to alter cell cycle effects of etoposide is due to any effect on down-regulation of $\mathrm{p} 21^{\mathrm{CIP} 1 / \mathrm{WAF} 1}$ expression. As seen in Fig. 5c, PES treatment had no apparent effect on etoposide-induced $\mathrm{p} 21^{\mathrm{CIP} 1 / \mathrm{WAF} 1}$ transcription. Again, this finding supports the suggestion that etoposide's effects are mediated largely through p53's functions at the mitochondria, unrelated to transcriptional regulation.

We next investigated the effect of PES treatment on CDK1/Cyclin B1 activity. Phosphorylation of CDK1 at the inhibitory site, Tyr15, is a key event controlling the G2/M switch. MEFs were treated with either etoposide alone or in combination with PES for 3 or $6 \mathrm{~h}$ and expression of phospho-Tyr15-CDK1 was investigated by immunoblotting. As shown in Fig. 5d, an increase in phospho-Tyr15-CDK1 was observed at 3 and $6 \mathrm{~h}$ post treatment with etoposide, as expected in cells blocked at G2/M. Pre-treatment with PES decreased the etoposideinduced CDK1 phosphorylation at both 3 and $6 \mathrm{~h}$. We next examined the effect of PES on Cyclin B1 expression, which is an absolute requirement for CDK1 activity. Similar to phospho-Tyr15-CDK1, an increase in Cyclin B1 expression was observed at 3 and $6 \mathrm{~h}$ post-etoposide treatment. Interestingly, the Cyclin B1 level was much 

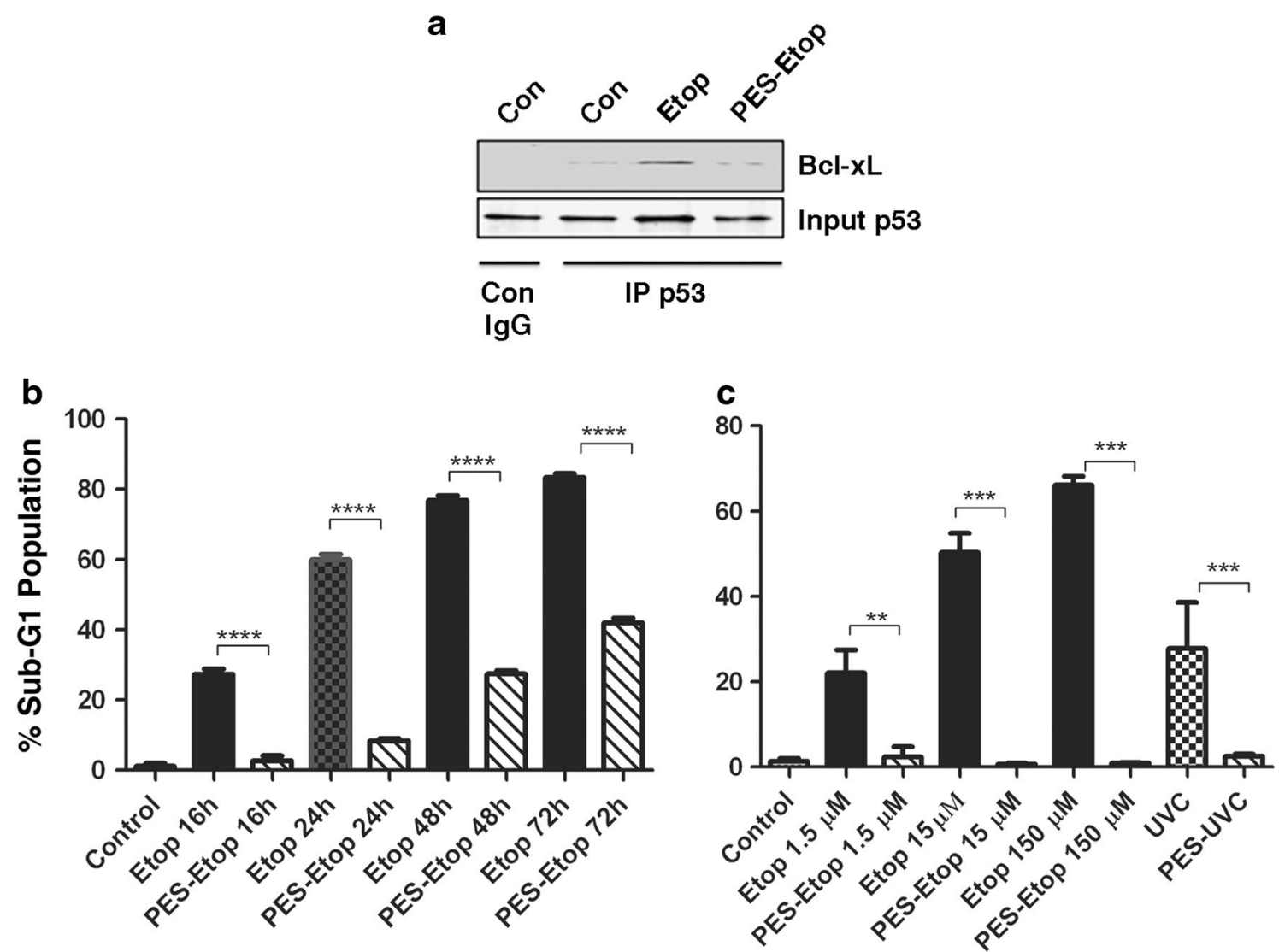

Fig. 4 Effect of PES on etoposide-induced cell death. a MEFs were either untreated (Con) or treated with etoposide (Etop) for 6 h, or pre-treated with $10 \mu \mathrm{M}$ of PES followed by $1.5 \mu \mathrm{M}$ of etoposide for $6 \mathrm{~h}$. Mitochondrial extracts were immunoprecipitated with anti-p53 antibody and probed for Bcl-xL. The first lane (IP Con IgG) represents mitochondrial extracts from untreated (Con) cells immunoprecipitated with rabbit lgG alone Input p53 represents the starting material unbound to the Agarose G beads, probed for the presence of p53. b MEFs were treated with either $1.5 \mu \mathrm{M}$ etoposide alone or pre-treated with $10 \mu \mathrm{M}$ of PES and followed by $1.5 \mu \mathrm{M}$ etoposide for various times. Columns represent percentage of cells having sub-G1 DNA content. A one-way ANOVA was carried out to compare the treatment groups. Post hoc comparison using the Tukey HSD test indicated significant inhibitory effect of PES treatment on the percentage of cells having sub-G1 DNA content. Data shown are mean + SD from 3 independent experiments with three replicates each. c Analysis of MEFs was done as in B; cells were pre-treated with $10 \mu \mathrm{M}$ PES followed by $18 \mathrm{~h}$ treatment with 1.5, 15 or $150 \mu \mathrm{M}$ etoposide. Cells were treated in parallel with UVC and followed for $18 \mathrm{~h}$. Statistical analysis was as in $\mathbf{b}$. Data are mean + SD of three repeat analyses.

lower in the presence of PES. A decrease in phosphoTyr15-CDK1/Cyclin B1 expression is consistent with cells escaping the G2 checkpoint arrest that normally occurs in response to etoposide treatment. Activation of Checkpoint kinase 1 (CHK1) blocks the entry into mitosis by phosphorylating members of CDC25 family of phosphatases, which activate cyclin B1-CDK1 through dephosphorylation of Thr14 and Tyr15 [32,33]. Hence, we next examined whether the inhibitory effect of PES on Tyr15-CDK1 was the consequence of CHK1 inhibition. We probed the same membrane with anti-phospho-Ser345 CHK1 antibody. Our results showed that, as expected, CHK1 was activated in response to etoposide treatment at 3 and $6 \mathrm{~h}$. Pre-treatment with PES resulted in a marked reduction in CHK1 activation which would eventually impede the cell cycle arrest by allowing the cells to enter mitosis. These results highlight several possible mechanisms by which PES treatment is overriding the etoposide-induced cell cycle arrest.

Treatment with etoposide causes G2 arrest by p53-dependent and independent pathways and either pathway can adequately cause G2 arrest [16]. The p53-dependent pathway can exert its inhibitory effects on cell cycle progression through either direct binding of p21 cip1/waf1 to CDK1 [34], down-regulation of CDK1/ Cyclin B1 protein levels [16] or $\mathrm{p} 21^{\text {cip1/waf1 }}$ mediated prevention of inhibitory phosphorylation of P130 and P107 by CDKs, which in turn represses the transcription of 


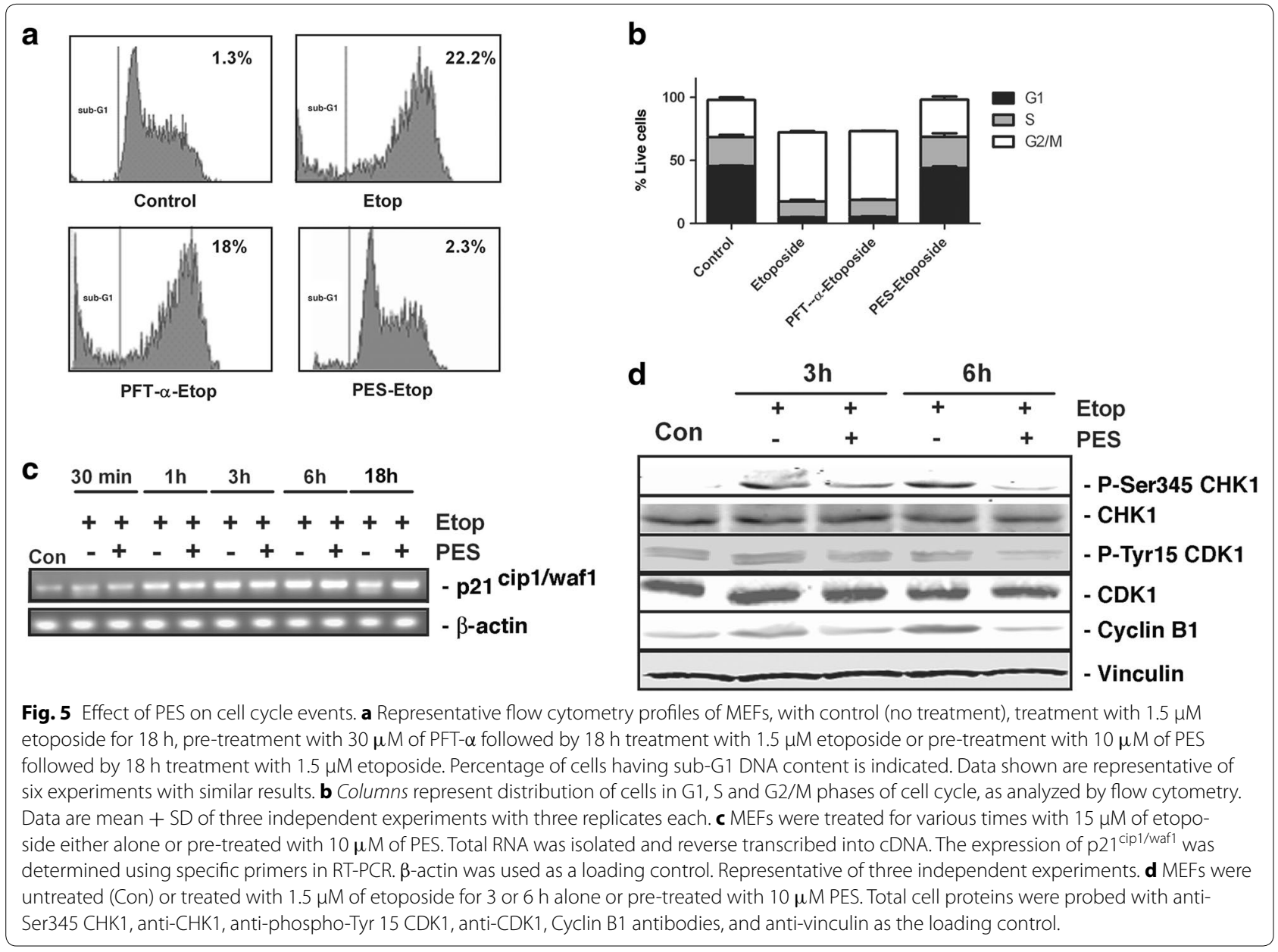

several genes required for progression through $\mathrm{G} 2 / \mathrm{M}$ [35]. The p53-independent pathway on the other hand is regulated by DNA damage response kinases ATM and ATR [36]. Our results showed that in response to treatment with $1.5 \mu \mathrm{M}$ of etoposide, the cells arrest at G2 through the p53-independent pathway and that PES is able to bypass it by inhibiting the phosphorylation of CHK1 on Ser 345 (Fig. 5d). These data contradict the findings of Balaburski et al. who showed that PES treatment leads to G2/M arrest by inhibiting the activity of Anaphase promoting complex/cyclosome and thus prevents the degradation of Cyclin B1 [37]. The reason for this apparent discrepancy is not clear as Balaburski et al. used HeLa cells in their studies and we have also confirmed that our results, first observed in MEFs, are also observed in HeLa cells.

\section{PES enhances deacetylation of Lys $373 / 382$ of $p 53$}

The stability and activity of p53 is regulated by posttranslational modifications [38]. In particular, acetylation of lysine residues in the $\mathrm{C}$-terminal regulatory domain of p53 has been shown to correlate well with the stability and activity of p53 [39]. We examined the effect of PES on the acetylation of Lys 373/382 of p53. Since MEFs used in the study were transformed using SV40 large T antigen, the p53 is constitutively acetylated at Lys 373/382. Interestingly when cells were treated with either PFT- $\alpha$ or PES alone, a decrease in Lys 373/382 acetylation of p53 was observed (data not shown). However, treatment of MEFs with PFT- $\alpha$ was unable to exert any effect on p53 acetylation when added with etoposide, while PES added in the presence of etoposide resulted in reduced acetylation on residues 373 and 382 (Fig. 6a).

\section{PES mediated deacetylation of p53 is not regulated by Mdm2-HDAC1}

Mdm2 has been shown to negatively regulate acetylation of p53 [38, 40]. The effect of Mdm2 on p53 acetylation was reported to result following recruitment of a complex containing Histone deacetylase 1 (HDAC1) [41]. We therefore sought to determine whether p53 in normally proliferating MEFs was bound to Mdm2 and whether 


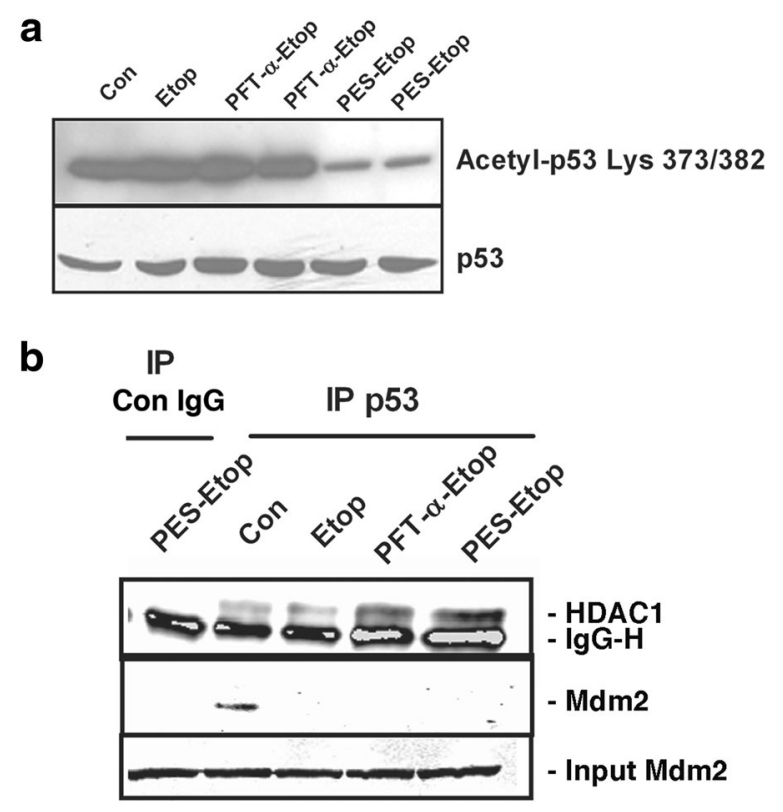

Fig. 6 Effect of drugs on p53 acetylation and complex formation. a MEFs were either left untreated (Con) or treated with etoposide (Etop) alone or in combination with either PFT- $\alpha$ or PES for $3 \mathrm{~h}$. Total cell extracts were prepared. The blot was probed with antiLys373/382 p53 antibody or anti-p53 as a loading control. b MEFs were either untreated (Con) or treated with etoposide (Etop) for $3 \mathrm{~h}$, or pre-treated with either $30 \mu \mathrm{M}$ of PFT- $\alpha$ or $10 \mu \mathrm{M}$ of PES followed by $1.5 \mu \mathrm{M}$ of etoposide for $3 \mathrm{~h}$. Total cell extracts were immunoprecipitated with anti-p53 antibody and probed for HDAC1 and Mdm2. The first lane (IP Con lgG) represents PES and etoposide-treated extracts immunoprecipitated with rabbit lgG alone to indicate position of the Ig heavy chain (lgGH). Input Mdm2 represents the starting material unbound to the Agarose $\mathrm{G}$ beads, probed for the presence of Mdm2.

treatment with PES would enhance recruitment of Mdm2-HDAC1 complex. We used co-immunoprecipitation studies to determine these interactions. Our results showed that in untreated MEF cells, p53 interacts with both endogenous $\mathrm{Mdm} 2$ as well as HDAC1. However, pre-treatment of cells with either PFT- $\alpha$ or PES resulted in an increase in Mdm2-independent p53/HDAC1 association. We did not observe an effect on the HDAC1 association upon treatment with etoposide alone. It is noteworthy that despite recruitment of HDAC1 to p53 in PFT- $\alpha$ treated MEFs, no deacetylation of p53 on Lys373/382 is observed in cells co-treated with etoposide (Fig. 6a, b) suggesting that presence of HDAC1 alone may not be sufficient for deacetylation.

p53 is transiently activated and stabilized in response to various stimuli by post-translational modifications. These modifications include phosphorylation [42], which has been shown to interfere with the ability of Mdm2 to negatively regulate p53 [43] and acetylation, which has been shown to promote p53 stability [41]. It is well established that Mdm2 ubiquitinates p53 on lysine residues $373 / 382$ and hence acetylation of these residues prevents the ubiquitin mediated turnover of p53 [38, 42]. Therefore, our finding that p53 is associated with Mdm2 and HDAC1 in MEFs that normally express p53 acetylated on Lysine 373/382 residues are intriguing. One explanation for these observations could be that the presence of another protein partner is required in the complex for efficient deacetylation. The pre-treatment with either PFT- $\alpha$ or PES, which affect p53 very differently, both caused increased recruitment of HDAC1 to p53. In this context it should be mentioned that recruitment of HDAC1 is Mdm2 independent and while PES causes deacetylation in the presence or absence of etoposide treatment, PFT- $\alpha$ deacetylates only when added alone. Etoposide and small molecule inhibitors PFT- $\alpha$ and PES have distinct activities related to their effects on p53 and perhaps the composition of the complex formed is a reflection of that. These observations are indeed intriguing and necessitate further investigation.

\section{Conclusion}

Despite decades of study in numerous experimental systems, the pathways by which p53 is regulated following treatment with etoposide, a commonly used drug for chemotherapy and a potent inducer of DNA damage, remain incompletely characterized. In this study, we asked whether etoposide induced cell death via p53 transcription-dependent events, or whether the mitochondrial events targeted by p53 were involved. Our first hint that transcription-dependent regulation by $\mathrm{p} 53$ is not required came from observations in which lower concentrations of etoposide were used. While the low concentration of etoposide was able to induce substantial cell death, it had no detectable effect on p53-dependent transcription. We next used known inhibitors of p53, PFT- $\alpha$ and PES, which target p53 transcriptional and mitochondrial functions, respectively. These compounds have both been reported to suppress death in mice exposed to radiation, and could thus be useful to block the harmful effects of chemotherapy that occur via p53-induced death. In our studies, PFT- $\alpha$ was able to suppress p53-mediated transcription induced by etoposide treatment. However, it was unable to suppress cell death induced by either low or high concentrations of etoposide. These results suggest that PFT- $\alpha$ cannot effectively block etoposide-induced death, despite blocking the induction of transcription via $\mathrm{p} 53$. On the other hand, PES was very effective in blocking etoposide-induced cell death, as determined by its ability to block the appearance of sub-G1 DNA content. We showed that PES may act in multiple ways to bypass the effects of etoposide, including (1) a dramatic effect in blocking etoposide-induced association of p53 
with the mitochondria (without any major effect on p53 total expression, (2) blocking the G2/M arrest induced by etoposide, likely via effects on Cyclin B1/CDK1, and (3) blocking acetylation of p53.

The in vivo relevance of the mitochondrial effects of p53 is emphasized by the observation that within $30 \mathrm{~min}$ of radiation or injection of a clinical dose of etoposide in drug sensitive organs, activation of caspase- 3 is observed, and this precedes detectable p53 dependent gene activation [44]. The significance of this observation has been underscored further by our observation that cell death still ensues when p53-dependent transcription is blocked for the duration of DNA damage. Based on these observations and those of others [45], we would like to stress that the p53 mitochondrial pathway is pivotal in exerting the lethal effects of chemo-/radiotherapy observed in sensitive cells.

In conclusion, our observation that a low, but clinically pertinent, concentration of etoposide is able to elicit death of cells whose p53 transcription function has been blocked has implications for use of etoposide in combination with chemotherapeutic agents that block transcription (reviewed by Ljungman and Lane [46]) or in tumors with mutations in the p53 DNA-binding core domain. To provide a fail-safe mechanism of eliminating cancerous cells, efforts could focus on enhancing the effects of p53 in causing cell death via its effects at the mitochondria. At the very least, our work supports effects to combine etoposide treatment in p53-inactive tumours, with agents that induce apoptosis via mitochondrial pathways dependent on BCL-2 family members.

\section{Methods}

\section{Cell lines}

Wild type MEFs (a kind gift from Dr. J. Opferman) were obtained from mixed 129/B6 background embryos harvested on E10.5. The primary P3 cells were immortalized by SV40 and cloned. Single cell clones were cultured in DMEM supplemented with 10\% fetal bovine serum.

\section{Antibodies and reagents}

Normal rabbit IgG and anti-actin (I-19) were purchased from Santa Cruz Biotechnology (Santa Cruz, CA, USA). Monoclonal anti-human vinculin was purchased from Sigma-Aldrich (Oakville, ON, USA). Rabbit anti-phospho-Tyr15 CDK1, rabbit anti-phospho-Ser345 CHK1, Bcl-xL and anti-caspase-3 antibodies were from Cell Signaling Technology (Beverly, MA, USA). Anti-CHK1 (D-7) and anti-cyclin B1 (H 433) were purchased from Santa Cruz Biotechnology (Santa Cruz, CA, USA). Rabbit polyclonal p53 antibody (CM5) was from Leica Microsystems (Concord, ON, USA), anti-acetyl-p53 (Lys 373, Lys 382) was from Millipore (Billerica, MA, USA) and anti-COX IV was from Abcam (Toronto, ON, USA). Etoposide, PFT- $\alpha$ and PES were purchased from Calbiochem (La Jolla, CA, USA). Fetal bovine serum and Protein-G Agarose beads were purchased from Invitrogen (Carlsbad, CA, USA).

\section{Cell treatments}

The stock solutions of etoposide, PFT- $\alpha$ and PES were prepared in DMSO. An equal amount of DMSO was added to the control cells in each experiment. MEFs were treated with $1.5,15$ or $150 \mu \mathrm{M}$ of etoposide for indicated periods of time. Pre-treatments with PFT- $\alpha$ or PES were carried out by incubation of cells with either $30 \mu \mathrm{M}$ of PFT- $\alpha$ or $10 \mu \mathrm{M}$ of PES for $10 \mathrm{~min}$ prior to the addition of etoposide. The UV irradiation was performed by removal of medium, washing once with PBS and exposure to a controlled dose of UVC (254 nm) light using an UltraLum cross-linker (Claremont, CA, USA).

\section{Immunoblotting}

Cells were washed with PBS and suspended in ice-cold solubilization buffer (20 mM Tris HCL pH 8.0, 1\% NP40, $10 \%$ glycerol, $137 \mathrm{mM} \mathrm{NaCl}, 10 \mathrm{mM} \mathrm{NaF}$, with Roche protease inhibitor cocktail) then sonicated for $5 \mathrm{~s}$ before centrifugation at $32,000 \times g$ for $5 \mathrm{~min}$. Equivalent concentrations of protein were resolved using SDS-polyacrylamide gel electrophoresis and transferred to nitrocellulose membranes. Membranes were blocked for $1 \mathrm{~h}$ in TBST$5 \%$ low-fat milk followed by overnight incubation at $4{ }^{\circ} \mathrm{C}$ with appropriate antibody and detection of IR-conjugated secondary antibodies using a LiCor Odyssey. The mitochondrial extracts were prepared by using mitochondria isolation kit for cultured cells (Thermo Scientific) according to the manufacturer's recommendations.

\section{Immunoprecipitation}

For immunoprecipitation of p53 complexes, total cell extracts were pre-cleared with $20 \mu \mathrm{l}$ of Protein G agarose beads for $30 \mathrm{~min}$. One $\mu \mathrm{g} / \mathrm{ml}$ anti-p53, or normal rabbit IgG antibody was added and after an overnight incubation, the immunoprecipitates were collected by adding $50 \mu \mathrm{l}$ of Protein G agarose beads. Beads were washed four times with solubilization buffer.

\section{RT-PCR and quantitative real-time PCR}

Total RNA was isolated from these cells using the GeneJet RNA purification kit (Thermo Scientific) according to the manufacturer's recommendations. Total RNA was reverse transcribed into cDNA using the RevertAid $\mathrm{H}$ minus reverse transcriptase (Thermo Scientific). The expression of $\mathrm{p} 21^{\mathrm{CIP} 1 / \mathrm{WAF} 1}$ was determined by RTPCR using specific primers (sequence described below). $\beta$-actin was used a loading control. 
For real-time PCR, amplification was performed using LightCyclerFastStart DNA Master Plus SYBR (Roche Applied Science, Mannheim, Germany) and using the comparative cycle threshold method $\left(2^{-\Delta \Delta C T}\right)$ to quantify gene expression. The mRNA levels were normalized to mouse $\beta$-actin expression (sense primer: $5^{\prime}$-GAGCACAG CTTCTTTGCAGCT- ${ }^{\prime}$ and antisense primer: $5^{\prime}$-CCCAC ATAGGAGTCCTTCTAGCC-3'). The primer sequences for the p21 were $5^{\prime}$-GTGTGCCGTTGTCTCTTCGG-3' and 5'-CTCAGGTAGACCTTGGGCAG-3'.

\section{Flow cytometry for cell cycle and subdiploid DNA staining}

Cells for flow cytometric analysis were fixed in $70 \%(\mathrm{v} / \mathrm{v})$ ethanol. The cells were subsequently stained in PBS containing $50 \mu \mathrm{g} / \mathrm{ml}$ of PI (propidium iodide), $100 \mu \mathrm{g}$ of RNase A and $0.1 \%$ glucose. Cells were analysed using BD FACSCanto II (BD Biosciences, San Jose, CA, USA).

\section{Additional file}

Additional file 1: Figure S1. Etoposide-induced apoptosis is concentration dependent. Representative flow cytometry analysis of control cells compared to treatment with various concentrations of etoposide. Cells were fixed and stained with propidium iodide as described. Cells with sub-G1 DNA content, or in G1, S and G2 phases of the cell cycle are indicated.

\section{Abbreviations}

CDK1: cyclin dependent kinase 1; CHK1: checkpoint kinase 1; HDAC1: histone deacetylase 1; MEF: mouse embryo fibroblast; PFT- $\alpha$ : pifithrin- $\alpha$; PES: 2-phenylethynesulfonamide; UVC: ultraviolet-C (short wavelength).

\section{Authors' contributions \\ SJ designed and executed a majority of the experiments. SJ also drafted the manuscript. IL generated data for Figs. 1a, 2a, 3a, 4b and 4c. MM generated data for Figs. $2 \mathrm{~b}$ and 5c. SHT generated data for Fig. 3b. VD supervised the project and critically evaluated the manuscript. All authors read and approved the final manuscript.}

\section{Acknowledgements}

We would like to thank Rouhallah Mousavizadeh and Payman Hojabrpour for help with data analyses. This work was supported by a Grant to VD from the Canadian Institutes of Health Research (MOP-74481).

\section{Compliance with ethical guidelines}

\section{Competing interests}

The authors declare that they have no competing interests.

Received: 28 May 2015 Accepted: 21 July 2015

Published online: 07 August 2015

\section{References}

1. Gudkov AV, Komarova EA (2007) Dangerous habits of a security guard: the two faces of p53 as a drug target. Hum Mol Genet. 16(Spec No 1):R67-R72. doi:10.1093/hmg/ddm052

2. Jiang L, Sheikh MS, Huang Y (2010) Decision Making by p53: Life versus Death. Mol Cell Pharmacol 2(2):69-77

3. Haldar S, Negrini M, Monne M, Sabbioni S, Croce CM (1994) Down-regulation of bcl-2 by p53 in breast cancer cells. Cancer Res 54(8):2095-2097
4. Miyashita T, Krajewski S, Krajewska M, Wang HG, Lin HK, Liebermann DA et al (1994) Tumor suppressor p53 is a regulator of bcl-2 and bax gene expression in vitro and in vivo. Oncogene 9(6):1799-1805

5. Zhan Q, Bieszczad CK, Bae I, Fornace AJ Jr, Craig RW (1997) Induction of BCL2 family member MCL1 as an early response to DNA damage. Oncogene 14(9):1031-1039. doi:10.1038/sj.onc.1200927

6. Miyashita T, Harigai M, Hanada M, Reed JC (1994) Identification of a p53-dependent negative response element in the bcl-2 gene. Cancer Res 54(12):3131-3135

7. Speidel D, Helmbold H, Deppert W (2006) Dissection of transcriptional and non-transcriptional p53 activities in the response to genotoxic stress. Oncogene 25(6):940-953. doi:10.1038/sj.onc.1209126

8. Johnson TM, Meade K, Pathak N, Marques MR, Attardi LD (2008) Knockin mice expressing a chimeric p53 protein reveal mechanistic differences in how p53 triggers apoptosis and senescence. Proc Natl Acad Sci USA 105(4):1215-1220. doi:10.1073/pnas.0706764105

9. Chipuk JE, Kuwana T, Bouchier-Hayes L, Droin NM, Newmeyer DD, Schuler $M$ et al (2004) Direct activation of Bax by p53 mediates mitochondrial membrane permeabilization and apoptosis. Science 303(5660):10101014. doi:10.1126/science.1092734

10. Chipuk JE, Bouchier-Hayes L, Kuwana T, Newmeyer DD, Green DR (2005) PUMA couples the nuclear and cytoplasmic proapoptotic function of p53. Science 309(5741):1732-1735

11. Golubovskaya VM, Cance WG (2013) Targeting the p53 pathway. Surg Oncol Clin N Am 22(4):747-764. doi:10.1016/j.soc.2013.06.003

12. Komarov PG, Komarova EA, Kondratov RV, Christov-Tselkov K, Coon JS, Chernov MV et al (1999) A chemical inhibitor of p53 that protects mice from the side effects of cancer therapy. Science 285(5434):1733-1737

13. Strom E, Sathe S, Komarov PG, Chernova OB, Pavlovska I, Shyshynova I et al (2006) Small-molecule inhibitor of p53 binding to mitochondria protects mice from gamma radiation. Nat Chem Biol 2(9):474-479. doi:10.1038/nchembio809

14. Leu Jl, Pimkina J, Frank A, Murphy ME, George DL (2009) A small molecule inhibitor of inducible heat shock protein 70. Mol Cell 36(1):15-27. doi:10.1016/j.molcel.2009.09.023

15. Burden DA, Kingma PS, Froelich-Ammon SJ, Bjornsti MA, Patchan MW, Thompson RB et al (1996) Topoisomerase II. Etoposide interactions direct the formation of drug-induced enzyme-DNA cleavage complexes. J Biol Chem 271(46):29238-29244

16. Clifford B, Beljin M, Stark GR, Taylor WR (2003) G2 arrest in response to topoisomerase II inhibitors: the role of p53. Cancer Res 63(14):4074-4081

17. Jamil S, Mojtabavi S, Hojabrpour P, Cheah S, Duronio V (2008) An essential role for MCL-1 in ATR-mediated CHK1 phosphorylation. Mol Biol Cell 19(8):3212-3220. doi:10.1091/mbc.E07-11-1171

18. Relling MV, Mahmoud HH, Pui CH, Sandlund JT, Rivera GK, Ribeiro RC et al (1996) Etoposide achieves potentially cytotoxic concentrations in CSF of children with acute lymphoblastic leukemia. J Clin Oncol 14(2):399-404

19. Hande KR, Wedlund PJ, Noone RM, Wilkinson GR, Greco FA, Wolff SN (1984) Pharmacokinetics of high-dose etoposide (VP-16-213) administered to cancer patients. Cancer Res 44(1):379-382

20. Minami H, Ando Y, Sakai S, Shimokata K (1995) Clinical and pharmacologic analysis of hyperfractionated daily oral etoposide. J Clin Oncol 13(1):191-199

21. Jamil S, Stoica C, Hackett TL, Duronio V (2010) MCL-1 localizes to sites of DNA damage and regulates DNA damage response. Cell Cycle 9(14):2843-2855

22. Komarova EA, Gudkov AV (2001) Chemoprotection from p53-dependent apoptosis: potential clinical applications of the p53 inhibitors. Biochem Pharmacol 62(6):657-667

23. Murphy PJ, Galigniana MD, Morishima Y, Harrell JM, Kwok RP, Ljungman M et al (2004) Pifithrin-alpha inhibits p53 signaling after interaction of the tumor suppressor protein with hsp90 and its nuclear translocation. J Biol Chem 279(29):30195-30201. doi:10.1074/jbc.M403539200

24. Sohn D, Graupner V, Neise D, Essmann F, Schulze-Osthoff K, Janicke RU (2009) Pifithrin-alpha protects against DNA damage-induced apoptosis downstream of mitochondria independent of p53. Cell Death Differ 16(6):869-878. doi:10.1038/cdd.2009.17

25. Gary RK, Jensen DA (2005) The p53 inhibitor pifithrin-alpha forms a sparingly soluble derivative via intramolecular cyclization under physiological conditions. Mol Pharm 2(6):462-474. doi:10.1021/mp050055d 
26. Leu Jl, George DL (2007) Hepatic IGFBP1 is a prosurvival factor that binds to BAK, protects the liver from apoptosis, and antagonizes the proapoptotic actions of p53 at mitochondria. Genes Dev 21(23):3095-3109. doi:10.1101/gad.1567107

27. Wolff S, Erster S, Palacios G, Moll UM (2008) p53's mitochondrial translocation and MOMP action is independent of Puma and Bax and severely disrupts mitochondrial membrane integrity. Cell Res 18(7):733-744. doi:10.1038/cr.2008.62

28. Mihara M, Erster S, Zaika A, Petrenko O, Chittenden T, Pancoska P et al (2003) p53 has a direct apoptogenic role at the mitochondria. Mol Cell 11(3):577-590

29. Leu Jl, Dumont P, Hafey M, Murphy ME, George DL (2004) Mitochondrial p53 activates Bak and causes disruption of a Bak-Mcl1 complex. Nat Cell Biol 6(5):443-450. doi:10.1038/ncb1123

30. Ubersax JA, Woodbury EL, Quang PN, Paraz M, Blethrow JD, Shah $\mathrm{K}$ et al (2003) Targets of the cyclin-dependent kinase Cdk1. Nature 425(6960):859-864. doi:10.1038/nature02062

31. Ding H, Duan W, Zhu WG, Ju R, Srinivasan K, Otterson GA et al (2003) P21 response to DNA damage induced by genistein and etoposide in human lung cancer cells. Biochem Biophys Res Commun. 305(4):950-956

32. Nilsson I, Hoffmann I (2000) Cell cycle regulation by the Cdc25 phosphatase family. Prog Cell Cycle Res 4:107-114

33. Nigg EA (2001) Mitotic kinases as regulators of cell division and its checkpoints. Nat Rev Mol Cell Biol 2(1):21-32. doi:10.1038/35048096

34. Xiong Y, Hannon GJ, Zhang H, Casso D, Kobayashi R, Beach D (1993) p21 is a universal inhibitor of cyclin kinases. Nature 366(6456):701-704. doi:10.1038/366701a0

35. Taylor WR, Stark GR (2001) Regulation of the G2/M transition by p53. Oncogene 20(15):1803-1815. doi:10.1038/sj.onc.1204252

36. Cliby WA, Roberts CJ, Cimprich KA, Stringer CM, Lamb JR, Schreiber SL et al (1998) Overexpression of a kinase-inactive ATR protein causes sensitivity to DNA-damaging agents and defects in cell cycle checkpoints. EMBO J 17(1):159-169. doi:10.1093/emboj/17.1.159

37. Balaburski GM, Leu Jl, Beeharry N, Hayik S, Andrake MD, Zhang G et al (2013) A modified HSP70 inhibitor shows broad activity as an anticancer agent. Mol Cancer Res 11(3):219-229. doi:10.1158/1541-7786. MCR-12-0547-T

38. Ito A, Lai CH, Zhao X, Saito S, Hamilton MH, Appella E et al (2001) p300/ CBP-mediated p53 acetylation is commonly induced by p53-activating agents and inhibited by MDM2. EMBO J 20(6):1331-1340. doi:10.1093/ emboj/20.6.1331

39. Olsson A, Manzl C, Strasser A, Villunger A (2007) How important are post-translational modifications in p53 for selectivity in target-gene transcription and tumour suppression? Cell Death Differ 14(9):1561-1575. doi:10.1038/sj.cdd.4402196

40. Kobet E, Zeng X, Zhu Y, Keller D, Lu H (2000) MDM2 inhibits p300-mediated $p 53$ acetylation and activation by forming a ternary complex with the two proteins. Proc Natl Acad Sci USA 97(23):12547-12552. doi:10.1073/pnas.97.23.12547

41. Ito A, Kawaguchi Y, Lai CH, Kovacs JJ, Higashimoto Y, Appella E et al (2002) MDM2-HDAC1-mediated deacetylation of p53 is required for its degradation. EMBO J 21(22):6236-6245

42. Appella E, Anderson CW (2001) Post-translational modifications and activation of p53 by genotoxic stresses. Eur J Biochem/FEBS 268(10):2764-2772

43. Unger T, Juven-Gershon T, Moallem E, Berger M, Vogt Sionov R, Lozano G et al (1999) Critical role for Ser20 of human p53 in the negative regulation of p53 by Mdm2. EMBO J 18(7):1805-1814. doi:10.1093/emboj/18.7.1805

44. Erster S, Mihara M, Kim RH, Petrenko O, Moll UM (2004) In vivo mitochondrial p53 translocation triggers a rapid first wave of cell death in response to DNA damage that can precede p53 target gene activation. Mol Cell Biol 24(15):6728-6741. doi:10.1128/MCB.24.15.6728-6741.2004

45. Vaseva AV, Moll UM (2009) The mitochondrial p53 pathway. Biochim Biophys Acta 1787(5):414-420. doi:10.1016/j.bbabio.2008.10.005

46. Ljungman M, Lane DP (2004) Transcription—guarding the genome by sensing DNA damage. Nat Rev Cancer 4(9):727-737. doi:10.1038/nrc1435

\section{Submit your next manuscript to BioMed Central and take full advantage of:}

- Convenient online submission

- Thorough peer review

- No space constraints or color figure charges

- Immediate publication on acceptance

- Inclusion in PubMed, CAS, Scopus and Google Scholar

- Research which is freely available for redistribution

Submit your manuscript at

www.biomedcentral.com/submit

C BioMed Central 